\title{
Synthesis and biological evaluation of phosphonated dihydroisoxazole nucleosides
}

\author{
Giovanni Romeo, ${ }^{\mathrm{a}, *}$ Daniela Iannazzo, ${ }^{\mathrm{a}}$ Anna Piperno, ${ }^{\mathrm{a}}$ Roberto Romeo, ${ }^{\mathrm{a}}$ \\ Monica Saglimbeni, ${ }^{a}$ Maria Assunta Chiacchio, ${ }^{\mathrm{b}}$ Emanuela Balestrieri, ${ }^{\mathrm{c}}$ \\ Beatrice Macchi $^{\mathrm{c}}$ and Antonio Mastino ${ }^{\mathrm{d}}$ \\ ${ }^{a}$ Dipartimento Farmaco-Chimico, Università di Messina, Via SS. Annunziata, Messina 98168, Italy \\ ${ }^{\mathrm{b}}$ Dipartimento di Scienze Chimiche, Università di Catania, Viale Andrea Doria 6, Catania 95125, Italy \\ 'Dipartimento di Neuroscienze, Università di Roma 'Tor Vergata', Via Montpellier 1 and IRCCS S. Lucia, Roma 00133, Italy \\ ${ }^{\mathrm{d}}$ Dipartimento di Scienze Microbiologiche, Genetiche e Molecolari, Università di Messina, Salita Sperone 31, Messina 98168, Italy
}

Received 29 August 2005; revised 11 January 2006; accepted 17 January 2006

Available online 15 February 2006

\begin{abstract}
Phosphonated isoxazolinyl nucleosides have been prepared via 1,3-dipolar cycloaddition reaction of nitrile oxides with corresponding vinyl or allyl nucleobases for antiviral studies. The cytotoxicity, the anti-HSV activity and the RT-inhibitory activity of the obtained compounds were evaluated and compared with those of AZT and diethyl $\left\{\left(1^{\prime} S R, 4^{\prime} R S\right)-1^{\prime}\right.$-[ [ (5-methyl-2,4-dioxo-3,4dihydropyrimidin-1(2H)-yl)]-3'-methyl-2'-oxa-3'-azacyclopent-4'-yl] methylphosphonate, a saturated phosphonated dihydroisoxazole nucleoside analogue.
\end{abstract}

(c) 2006 Elsevier Ltd. All rights reserved.

\section{Introduction}

In the last two decades, nucleosides and nucleotides have become an important subject of research in the field of medicinal chemistry following the discovery that the structural modification of natural derivatives can offer important synthetic routes for the preparation of new bioactive nucleoside analogues. ${ }^{1}$ Extensive modifications have been performed on both the heterocyclic base as well as on the sugar moiety. ${ }^{2}$ In this context, nucleoside analogues, in which the furanose ring has been substituted by acyclic, ${ }^{3}$ carbocyclic, ${ }^{4}$ and heterocyclic moieties, ${ }^{5}$ have attracted special interest by virtue of their biological action as antiviral and anticancer agents. In this field, a recent line of research considers the replacement of the ribose ring with an isoxazolidine nucleus: since the pioneering work of Tronquet et al., ${ }^{6}$ isoxazolidine nucleosides have emerged as an interesting class of dideoxynucleoside analogues whose structures

\footnotetext{
Keywords: Phosphonated nucleosides; Antiviral agents; 1,3-Dipolar cycloaddition; Isoxazoline nucleotides.

* Corresponding author. Tel.: +39 090 6766562; fax: +39 090

355613; e-mail: gromeo@unime.it
}

hold good potential for the development of biologically active compounds.

Our efforts in this area have been devoted towards the development of new schemes for the enantioselective synthesis of $\mathrm{N}, \mathrm{O}$-modified nucleosides 1-3. ${ }^{7}$ Some of the obtained compounds exhibit interesting biological features in vitro: in particular, (-)-ADFU 1 (B = 5-fluorouracil), while showing low levels of cytotoxicity, has been shown to be a good inductor of apoptosis on lymphoid and monocytoid cells, acting as a strong potentiator of Fas-induced cell death. ${ }^{8}$ Also the dihydroisoxazole ring could constitute a suitable substrate for the synthesis of new antiviral compounds. Hydroxymethyl dihydroisoxazole nucleosides $\mathbf{4}$ have been reported to exhibit in vitro moderate anti-HIV activity and moderate cytotoxicity; thus representing the first example of potential antiviral agents which derive from dihydroisoxazole nucleus (Fig. 1). ${ }^{9}$

However, it is well known that most of these nucleoside analogues must be phosphorylated by cellular kinases to give successively $5^{\prime}$-mono-, di- and tri-phosphates; ${ }^{10}$ in this latter form, they are metabolized by enzymatic systems, instead of natural nucleosides, and inserted in the DNA growing chain, acting as chain terminators. 
<smiles>[B]C1CCNOC1</smiles><smiles>[R]N1O[C@@H]([B])CC[C@@H]1CO</smiles>

$\mathrm{HO}-$

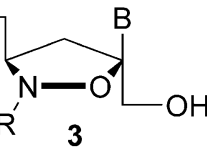

1<smiles>[B]C1CONC(CO)C1</smiles><smiles>CCOC(=O)N(C)CCP(=O)(OCC)OCC</smiles>

$\mathrm{B}=$ Thymine, Cytosine, Adenine,5-Fluorouracil $\mathrm{R}=\mathrm{H}, \mathrm{CH}_{3}, \mathrm{Bn}$

Figure 1. $\mathrm{N}, \mathrm{O}$-Nucleosides.

Several strategies have been envisaged to overcome the problem of the initial selective monophosphorylation step. ${ }^{11}$ In this respect, a good approach involves the design of isosteric and isoelectronic phosphonates which are resistant to enzymatic dephosphorylation and able to penetrate cell membranes functioning as mimetics of the corresponding monophosphates. ${ }^{12}$

Recently, we have described the reverse transcriptase (RT) inhibitors 5: these compounds show low levels of cytotoxicity and exert, on the RT from two different retroviruses, a specific inhibitory activity, which is comparable with that of AZT, thus opening up new perspective on their possible use as therapeutic agents, in antiretroviral and anti-HBV chemotherapy. ${ }^{13}$

Phosphonated nucleosides can be divided in two classes: (a) 'foreshortened' phosphonates, where the nucleic acid base is separated from the phosphorus by a chain of four atoms, one atom shorter than in the corresponding nucleoside phosphates; (b) 'full-length' analogues, where the five atom chain of nucleotides is preserved. ${ }^{14}$ Examples of nucleoside phosphonates with antiviral activity include foreshortened analogues ${ }^{15,12}$ as well as fulllength derivatives. ${ }^{16}$

Considering all these aspects and in connection with our studies on $\mathrm{N}, \mathrm{O}$-modified nucleosides, we deemed interesting to see whether phosphonated isoxazoline derivatives could be utilized as antiviral agents in the future. In this paper, we report the synthesis of 'foreshortened' and 'full-length' phosphonated nucleosides $\mathbf{6}$ and 7 containing a dihydroisoxazole skeleton (Fig. 2). The synthesis of this kind of compounds could throw light on the structural features which concur to determine the biological activity of the $N, O$-nucleoside system.
The cytotoxicity, the anti-HSV activity and the RT-inhibitory activity of the obtained compounds have been investigated and compared with those of saturated phosphonated dihydroisoxazole nucleosides $\mathbf{5}$.

\section{Results and discussion}

The synthetic strategy towards the construction of isoxazolin-5-yl nucleosides 6 and 7 relies on the 1,3-dipolar cycloaddition approach. In this aim, a suitable dipole is represented by the nitrile oxide originated from diethyl 2-(hydroxymino)ethyl phosphonate $\mathbf{8}^{17}$ which have been reacted with vinyl ${ }^{18}$ or allyl ${ }^{19}$ nucleobases $\mathbf{1 0}$ and $\mathbf{1 2 .}$

\subsection{A. Foreshortened phosphonates}

The synthesis of compounds $\mathbf{6 a}-\mathbf{c}$ has been performed in a one-step process as shown in Scheme 1. The nitrile oxide $\mathbf{9}$, derived in situ from aldoxime $\mathbf{8}$ by treatment with $N$-bromosuccinimide under basic condition, was added to the vinyl nucleobases $\mathbf{1 0 a}-\mathbf{c}$ to give the racemic isoxazolin-5-yl nucleosides $\mathbf{6 a - c}$ in $60-70 \%$ yield (Scheme 1).

The two-step methodology previously reported, ${ }^{20}$ based on the 1,3-dipolar cycloaddition of 9 with vinyl acetate and followed by Vorbrüggen nucleosidation, always led to the expected diethyl(isoxazol-3-yl)methylphosphonate as an exclusive product.

In agreement with analogous cycloaddition processes, the reaction showed a complete regioselectivity and the 5-isomer was obtained, after purification, as the sole product. ${ }^{21}$ The ${ }^{1} \mathrm{H}$ NMR of the crude reaction mixture did not show any trace of the alternative 4-isomer. Structures of all the obtained adducts were supported by their spectral and analytical data.

The ${ }^{1} \mathrm{H}$ NMR spectrum of $\mathbf{6 a}$, chosen as model compound, displays the vinyl proton of the thymine unit as a quartet at $7.04 \mathrm{ppm}$ and the methyl group as a doublet at $1.98 \mathrm{ppm}$. The $\mathrm{H}-5$ proton resonates as doublet of doublet at $6.70 \mathrm{ppm}(J=3.9$ and $6.5 \mathrm{~Hz})$. The methylene protons at C-4 appear as two separate doublets of doublets at 3.72 and $3.19 \mathrm{ppm}$. The methylene protons of the phosphonate moiety resonate as two separate doublets at 2.95 and $3.10 \mathrm{ppm}$. The ${ }^{13} \mathrm{C}$ NMR spectrum of $6 \mathbf{a}$ shows the characteristic resonance of the $\mathrm{C}=\mathrm{N}$ group at $150.3 \mathrm{ppm}$. The structures of derivatives $\mathbf{6 b}$ and $\mathbf{c}$ were assigned on the basis of similar observations.

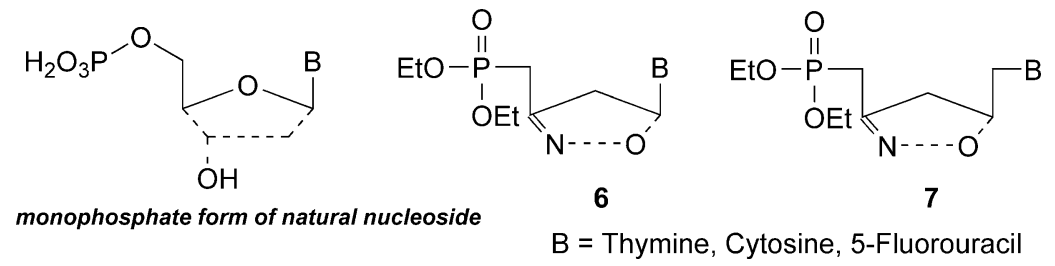

Figure 2. Nucleoside phosphate and phosphonates. 

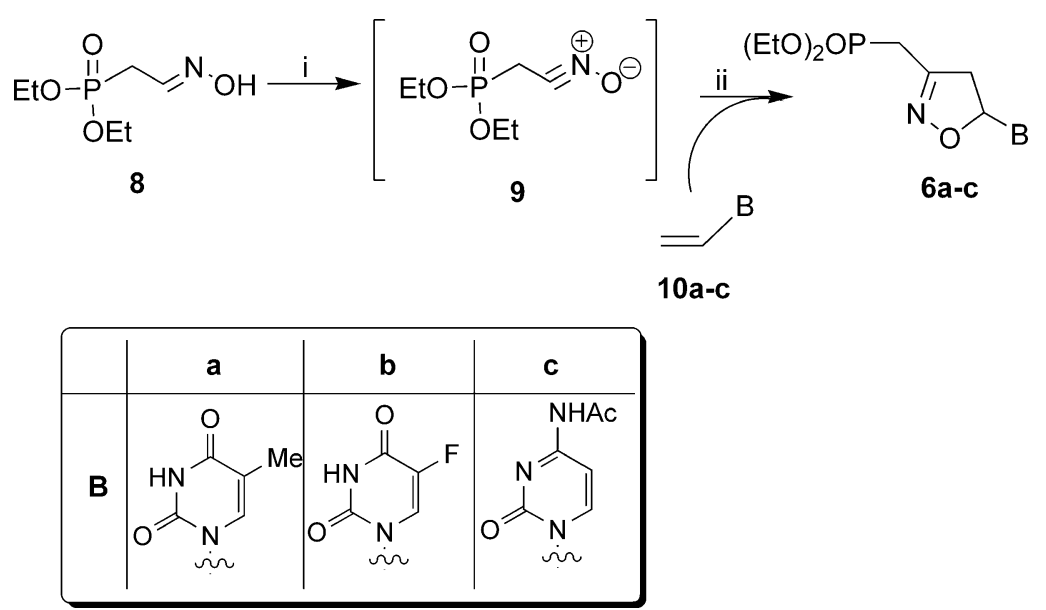

Scheme 1. Reagents and conditions: (i) NCS, TEA, $\mathrm{CH}_{2} \mathrm{Cl}_{2}, 1 \mathrm{~h}$, rt; (ii) 10a-c, $12 \mathrm{~h}, 40-50{ }^{\circ} \mathrm{C}(60-70 \%)$.

\subsection{B. Full-length phosphonates}

Normal nucleosides have a $\mathrm{N}$-glycosidic linkage which determines the typical conformational preferences of natural nucleosides. ${ }^{22}$ When a methylene group is inserted between the $\mathrm{N}-1$ of the heterocyclic bases and C-1' of the pentofuranosyl ring, the anomeric effect is lost. Moreover, the heterocyclic base moiety occupies a more flexible position ${ }^{23}$ and the so formed nucleosides possess less specific and less restrictive interactions with the receptorial site.

The synthesis of homo- $N$-nucleosides $7 \mathbf{a}-\mathbf{c}$ has been carried out according to Schemes 2 and 3. The first approach was based on the 1,3-dipolar cycloaddition of nitrile oxide 9 with allyl alcohol. The obtained cycloadduct $\mathbf{1 1}^{24}$ was then converted into the corresponding $O$-methanesulfonyl derivative upon treatment with methanesulfonyl chloride in the presence of triethylamine and was directly treated with thymine, fluorouracil or cytosine, in the presence of sodium hydride or caesium carbonate in dimethylformamide at $90{ }^{\circ} \mathrm{C}$. Nucleosides 7a-c were obtained in low yields and in the crude reaction mixture $\mathrm{N}-3$ pyrimidine isomers were observed (Scheme 2).

Pyrimidine anions are less regioselective in their reactions with several electrophiles. Thus, alkylation of the

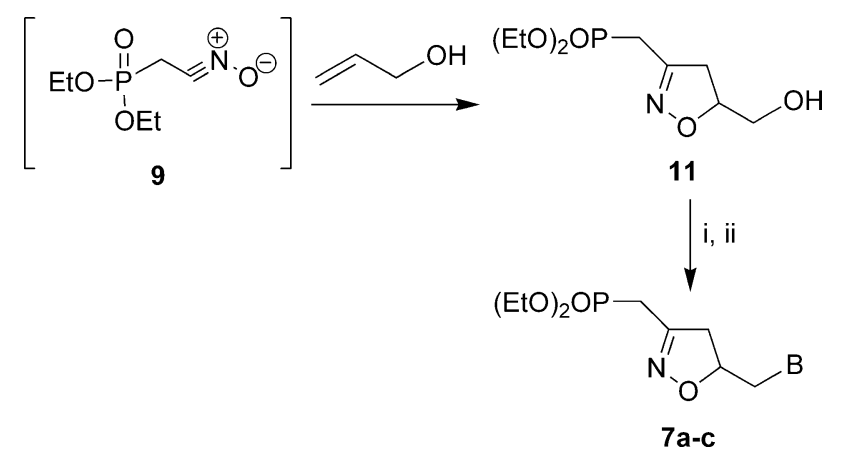

Scheme 2. Reagents and conditions: (i) $\mathrm{MsCl}, \mathrm{TEA}, \mathrm{CH}_{2} \mathrm{Cl}_{2}, 2 \mathrm{~h}$, rt; (ii) pyrimidine nucleobases, caesium carbonate, dimethylformamide, $12 \mathrm{~h}, 90^{\circ} \mathrm{C}$. pyrimidine nucleobases can generally occur at the $\mathrm{N}-1$ as well as the N-3 positions, although alkylation at $\mathrm{N}-1$ predominates. ${ }^{25}$

In order to overcome the problem of the N-regioselectivity and the low yields, the alternative synthetic procedure, based on the 1,3-dipolar cycloaddition reaction of nitrile oxide 9 with allyl nucleobases, was performed (Scheme 3). The reaction proceeded with good yields $(70-75 \%)$ to give racemic nucleosides $7 \mathbf{a}-\mathbf{c}$, which have been purified by MPLC chromatography $\left(\mathrm{CHCl}_{3} /\right.$ $\mathrm{MeOH}, 99: 1)$.

The structure of nucleosides $\mathbf{7 a - c}$ has been confirmed by ${ }^{1} \mathrm{H}$ NMR. As an example, the ${ }^{1} \mathrm{H}$ NMR spectrum of 7 shows $\mathrm{H}-4$ protons as two doublets of doublets centered at 2.98-3.01 and 3.01-3.12 ppm, while $\mathrm{H}-5$ resonates as multiplet at $4.93-4.96 \mathrm{ppm}$. The methylene group at C-5 resonates as two doublets of doublets in the range of $3.60-4.95 \mathrm{ppm}$ while the methylene protons of the phosphonate moiety resonate as multiplet at $2.95-3.02 \mathrm{ppm}$.

\section{Biological tests}

The synthesized compounds, $\mathbf{6 a}-\mathbf{c}$ and $\mathbf{7 a}-\mathbf{b}$, were tested in vitro for their cytotoxicity, on Molt-3 and Vero cells. Moreover, the antiviral activity against herpes simplex viruses (HSV-1 and HSV-2) and the inhibitory activity versus retroviral RT, along with reference antiviral compounds (acyclovir for anti-HSV and AZT for RT-inhibition), were assayed. Results are shown in Table 1.

None of the above mentioned synthetized phosphonated nucleosides, when evaluated against HSV-1 and HSV-2 by means of a standard plaque reduction assay in Vero cells, showed specific anti-HSV activity, that is, an $\mathrm{EC}_{50}$ lower than the minimal $\mathrm{CC}_{20}$ detected in one of the two cell lines tested, as we arbitrarily defined. As expected, the reference compound acyclovir confirmed its specific, strong anti-HSV activity.

The ability to inhibit the reverse transcriptase activity of avian myeloblastosis retrovirus was tested in a cell-free 

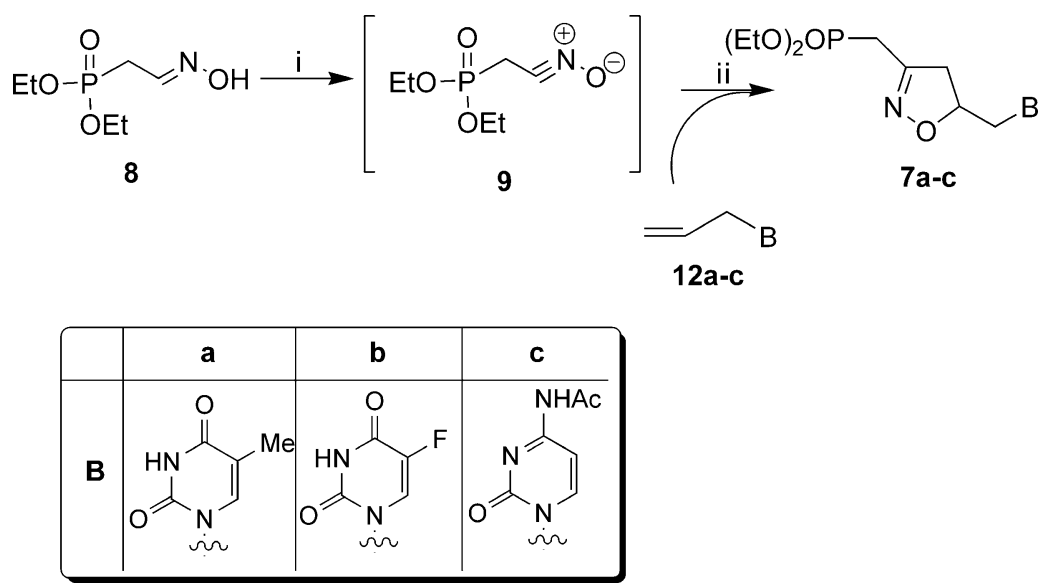

Scheme 3. Reagents and conditions: (i) NBS, TEA, $\mathrm{CH}_{2} \mathrm{Cl}_{2}, 1 \mathrm{~h}$, rt; (ii) $12 \mathrm{a}-\mathbf{c}, 12 \mathrm{~h}, 60^{\circ} \mathrm{C}(70-75 \%)$.

Table 1. Evaluation of cytotoxicity, ${ }^{\mathrm{a}}$ anti-HSV activity ${ }^{\mathrm{b}}$ and RT-inhibitory activity ${ }^{\mathrm{c}}$ of phosphonated nucleosides in vitro

\begin{tabular}{|c|c|c|c|c|c|}
\hline \multirow[t]{2}{*}{ Compound } & \multicolumn{2}{|c|}{ Toxicity $\mathrm{CC}_{20}$} & \multirow{2}{*}{$\begin{array}{l}\text { HSV-1 plaque reduction assay } \\
\mathrm{EC}_{50}\end{array}$} & \multirow{2}{*}{$\begin{array}{l}\text { HSV-2 plaque reduction assay } \\
\mathrm{EC}_{50}\end{array}$} & \multirow{2}{*}{$\begin{array}{l}\text { RT-inhibition assay } \\
\text { EC }_{100}\end{array}$} \\
\hline & MOLT-3 & VERO & & & \\
\hline Acyclovir & $>400$ & $>400$ & 3.00 & 3.70 & $\mathrm{ND}^{\mathrm{d}}$ \\
\hline AZT & $\mathrm{ND}^{\mathrm{d}}$ & $\mathrm{ND}^{\mathrm{d}}$ & $\mathrm{ND}^{\mathrm{d}}$ & $\mathrm{ND}^{\mathrm{d}}$ & $10 \mathrm{nM}$ \\
\hline $5 a^{e^{e}}$ & $>400$ & $>400$ & $>400$ & $>400$ & $10 \mathrm{nM}$ \\
\hline $6 \mathbf{a}$ & $>400$ & $>400$ & $>400$ & $>400$ & $10 \mu \mathrm{M}$ \\
\hline $6 \mathbf{b}$ & 76.62 & $>400$ & $>100$ & $>100$ & $\mathrm{ND}^{\mathrm{d}}$ \\
\hline $6 c$ & 120.00 & $>400$ & $>200$ & $>200$ & $10 \mu \mathrm{M}$ \\
\hline $7 \mathbf{a}$ & $>400$ & $>400$ & $>400$ & $>400$ & $10 \mu \mathrm{M}$ \\
\hline $7 \mathbf{b}$ & $>400$ & $>400$ & $>400$ & $>400$ & $>10 \mu \mathrm{M}$ \\
\hline
\end{tabular}

${ }^{a}$ Cells were exposed under optimal culture conditions to concentrations of acyclovir, 5a, 6a-c and $7 \mathbf{a}, \mathbf{b}$ ranging from $1 \mathrm{nM}$ to $400 \mu \mathrm{M}$, or control medium. Values indicate the $\mathrm{CC}_{20}$ calculated as the concentrations of the drug required to cause $20 \%$ toxicity, detected by a commercial viability assay (CellTiter $96^{\circledR}$ AQueous One Solution Assay, Promega Co., Madison WI).

${ }^{\mathrm{b}} \mathrm{HSV}-1$ and HSV-2 antiviral activity was assayed by standard plaque reduction assays on Vero cells in six-well plates at concentrations ranging from 1 to $400 \mu \mathrm{M}$. Values indicate $\mathrm{EC}_{50}$ as the concentrations of the compounds required to cause $50 \%$ reduction of plaque formation.

${ }^{\mathrm{c}}$ Inhibition of reverse transcriptase activity was evaluated by a cell free assay based on a RT-PCR at concentrations ranging from $10 \mu \mathrm{M}$ to $1 \mathrm{nM}$. Values indicated $\mathrm{EC}_{100}$ as the concentrations of the compounds required to cause complete $(100 \%)$ inhibition of RT-PCR products.

${ }^{\mathrm{d}}$ Not done.

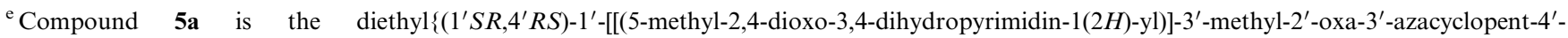
yl] methylphosphonate.

assay. ${ }^{13}$ Compounds 6a,c and 7a completely inhibited the RT activity at the higher concentration tested, that is, at $10 \mu \mathrm{M}$. This concentration is 1000 -fold higher than that shown by the reference compound AZT and by the compounds 5 to exert the same effect. Nevertheless, the compounds generally showed a low level of toxicity. None of the compounds tested showed a $\mathrm{CC}_{20}$ lower than the maximal concentration tested on Vero cells, while compounds $\mathbf{6 b}$ and $\mathbf{c}$ showed a certain degree of cytotoxicity on Molt-3 cells.

Taken all together, these results indicate that the insertion of an unsaturation in the pseudosugar moiety leads to molecules with lower potency with respect to isoxazolidine derivatives 5 . The reduced efficacy of these compounds towards RT may be attributed to two fundamental factors: (1) lower molecular flexibility and (2) lower basicity of the nitrogen atom.

The introduction of a double bond on the $\mathrm{N}, \mathrm{O}$-heterocyclic moiety decreased the flexibility of the five-membered ring so determining a less ability to elicit recognition by reverse transcriptase, with respect to compounds previously described by us. ${ }^{13}$ Moreover, it is known that the insertion of nucleotides in the growing nucleic acid chain operated by polymerases is assisted by bivalent metallic ions that facilitate the transfer of nucleotide units. ${ }^{26}$ In phosphonated nucleosides, one of these ions links the phosphorus moiety and the heteroatom that lies between the nucleobase and the phosphorus. In phosphonated $2^{\prime}$-oxa- $3^{\prime}$-aza-nucleosides $\mathbf{5}$, the heteroatom responsible for this binding is probably the nitrogen atom. In fact, coordinating metal ions (e.g., $\mathrm{Mg}^{2+}$ ) can form a six-membered chelate with the nitrogen atom and the oxygen of phosphonyl group. For unsaturated compounds 6-7, the lower basicity of nitrogen atom could account for the reduced activity towards AMV-RT.

\section{Conclusions}

'Foreshortened' and 'full-length' phosphonated dihydroisoxazole nucleosides containing thymine, fluorouracil 
and cytosine have been synthesized in good yields by the 1,3-dipolar cycloaddition methodology.

The cytotoxicity, the anti-HSV activity and the RTinhibitory activity of the obtained compounds have been investigated and compared with that of AZT and with that of saturated phosphonated isoxazolidinyl nucleosides 5. The RT-inhibitory activity of the obtained compounds is 1000-fold lower than that of the lead compound 5. The insertion of a double bond in the sugar moiety not only does not potentiate but actually reduces the nucleotide capability to function as a chain terminator, so excluding the possibility that the investigated compounds can be considered at the moment as promising inhibitors of retroviral RT. Further efforts are needed to further modify the $N, O$-system, in order to achieve new nucleoside phosphonates with a better biological activity with respect to compounds $\mathbf{5}$.

\section{Experimental}

\subsection{General}

Commercially available chemicals and solvents were of reagent grade. All solvents were dried according to literature methods. Elemental analyses were performed on a Perkin-Elmer 220B microanalyzer. NMR spectra were recorded on a Varian instrument at $300 \mathrm{MHz}(1 \mathrm{H})$ and at $75 \mathrm{MHZ}\left({ }^{13} \mathrm{C}\right)$ using deuterochloroform as solvent; chemical shifts are given in parts per million from TMS as internal standard. Thin-layer chromatographic separations were achieved with Merck silica gel 60F254 precoated aluminium plates. Preparative separations were carried out by MPLC Büchi C-601 using Merck silica gel $0.040-0.063 \mathrm{~mm}$.

\subsection{General procedure for the synthesis of nucleosides $6 \mathrm{a}-\mathrm{c}$ and $7 \mathrm{a}-\mathrm{c}$}

To a stirring suspension of $N$-chlorosuccinimide $(5.1 \mathrm{mmol})$ in dry $\mathrm{CH}_{2} \mathrm{Cl}_{2}(10 \mathrm{ml})$, a solution of diethyl 2-(hydroxymino)ethyl phosphonate 8 (5.1 mmol, $1 \mathrm{~g}$ ) in dry $\mathrm{CH}_{2} \mathrm{Cl}_{2}(10 \mathrm{ml})$ was added, together with a catalytic amount of pyridine. As the suspended $N$-chlorosuccinimide completely disappeared, the vinyl or allyl nucleobases $(5 \mathrm{mmol})$ in dry $\mathrm{CH}_{2} \mathrm{Cl}_{2}(10 \mathrm{ml})$ were added dropwise and the temperature was raised to $40-50{ }^{\circ} \mathrm{C}$. After $10 \mathrm{~min}$ of stirring at this temperature, triethylamine $(5.1 \mathrm{mmol})$ was added dropwise over $15 \mathrm{~min}$ and the mixture was stirred for another $12 \mathrm{~h}$. The solvent was evaporated under reduced pressure and the residue was chromatographed by MPLC Büchi C-601, using $\mathrm{CHCl}_{3} / \mathrm{MeOH}(99: 1)$ as solvent $(10 \mathrm{ml} / \mathrm{min})$.

\subsection{Diethyl[(5RS)-4,5-dihydro-5-(3,4-dihydro-5-methyl- 2,4-dioxopyrimidin- 1(2H)-yl)isoxazol-3-yl] methyl phosphonate 6a}

Starting from diethyl 2-(hydroxymino)ethyl phosphonate, compound $6 \mathbf{a}$ was obtained as a yellow oil $(70 \%$ yield). ${ }^{1} \mathrm{H} \mathrm{NMR}\left(\mathrm{CDCl}_{3}\right): \delta 1.31(\mathrm{t}, 6 \mathrm{H}, J=5.9 \mathrm{~Hz})$, $1.98(\mathrm{~d}, 3 \mathrm{H}, J=0.95 \mathrm{~Hz}), 2.95(\mathrm{dd}, 1 \mathrm{H}, J=13.5$ and $\left.21.5 \mathrm{~Hz}, \mathrm{H}_{3^{\prime \prime} \mathrm{a}}\right), 3.01(\mathrm{dd}, 1 \mathrm{H}, J=13.5$ and $22.1 \mathrm{~Hz}$, $\left.\mathrm{H}_{3^{\prime \prime} \mathrm{b}}\right), 3.09$ (dd, $1 \mathrm{H}, J=3.9$ and $\left.9.5 \mathrm{~Hz}, \mathrm{H}_{4^{\prime} \mathrm{a}}\right), 3.51$ $(\mathrm{dd}, 1 \mathrm{H}, J=6.5$ and $9.5 \mathrm{~Hz}), 4.05(\mathrm{q}, 4 \mathrm{H}, J=5.9 \mathrm{~Hz})$, $6.70(\mathrm{dd}, 1 \mathrm{H}, J=3.9$ and $6.5 \mathrm{~Hz}), 7.05(\mathrm{q}, 1 \mathrm{H}$, $\left.J=0.95, \mathrm{H}_{6}\right), 10.01$ (br s, NH). ${ }^{13} \mathrm{C} \mathrm{NMR}\left(\mathrm{CDCl}_{3}\right): \delta$ $12.32,16.21,25.61,43.70,62.86,84.55,95.05,111.94$, 134.78, 150.25, 152.63, 163.56. HRMS (FAB) calcd for $\left[\mathrm{M}^{+}\right] \mathrm{C}_{13} \mathrm{H}_{20} \mathrm{~N}_{3} \mathrm{O}_{6} \mathrm{P}: 345.2944$. Found: 345.2941. Anal. Calcd for $\mathrm{C}_{13} \mathrm{H}_{20} \mathrm{~N}_{3} \mathrm{O}_{6} \mathrm{P}$ : C, 45.22; H, 5.84; N, 12.17 . Found: C, 45.29; H, 5.79; N, 12.23.

5.4. Diethyl[(5RS)-5-(5-fluoro-3,4-dihydro-2,4-dioxopyrimidin-1(2H)-yl)-4,5-dihydroisoxazol-3-yl] methyl phosphonate $6 \mathrm{~b}$

Starting from diethyl 2-(hydroxymino)ethyl phosphonate, compound $\mathbf{6 b}$ was obtained as a yellow oil $(67 \%$ yield). ${ }^{1} \mathrm{H}$ NMR $\left(\mathrm{CDCl}_{3}\right): \delta 1.35(\mathrm{t}, 6 \mathrm{H}, J=6.8 \mathrm{~Hz})$, $2.96\left(\mathrm{dd}, 1 \mathrm{H}, J=14.8\right.$ and $\left.22.0 \mathrm{~Hz}, \mathrm{H}_{3^{\prime \prime} \mathrm{a}}\right), 3.18$ (dd, $1 \mathrm{H}, \quad J=14.8$ and $\left.21.47 \mathrm{~Hz}, \mathrm{H}_{3^{\prime \prime} \mathrm{b}}\right), 3.13(\mathrm{dd}, 1 \mathrm{H}$, $J=2.03$ and $\left.12.5 \mathrm{~Hz}, \mathrm{H}_{4^{\prime} \mathrm{a}}\right), 3.60(\mathrm{dd}, 1 \mathrm{H}, J=8.7$ and $12.5 \mathrm{~Hz}), 4.10(\mathrm{q}, 4 \mathrm{H}, J=6.8 \mathrm{~Hz}), 6.70(\mathrm{dd}, 1 \mathrm{H}$, $J=2.03$ and $8.7 \mathrm{~Hz}), 7.35\left(\mathrm{~d}, 1 \mathrm{H}, J=5.8 \mathrm{~Hz}, \mathrm{H}_{6}\right), 9.80$ (bs, NH). ${ }^{13} \mathrm{C}$ NMR $\left(\mathrm{CDCl}_{3}\right): \delta 16.47,16.57,25.99$, $44.21,63.35,63.51,85.38,94.72, \quad 126.65, \quad 149.04$, 153.45, 157.49. HRMS (FAB) calcd for $\left[\mathrm{M}^{+}\right]$ $\mathrm{C}_{12} \mathrm{H}_{17} \mathrm{~N}_{3} \mathrm{O}_{6} \mathrm{FP}:$ 349.2594. Found: 349.2590. Anal. Calcd for $\mathrm{C}_{12} \mathrm{H}_{17} \mathrm{~N}_{3} \mathrm{O}_{6} \mathrm{FP}$ : C, 41.27; H, 4.91; N, 12.03 . Found: C, 41.22; H, 4.86; N, 12.08.

5.5. [(5RS)-5-(4-Acetylamino-2-oxo-2H-pyrimidin-1-yl)4,5-dihydroisoxazol-3-ylmethyl] phosphonic acid diethyl ester 6c

Starting from diethyl 2-(hydroxymino)ethyl phosphonate, compound $\mathbf{6 c}$ was obtained as a yellow oil $(60 \%$ yield). ${ }^{1} \mathrm{H} \mathrm{NMR}\left(\mathrm{CDCl}_{3}\right): \delta 1.37(\mathrm{t}, 6 \mathrm{H}, J=6.5 \mathrm{~Hz})$, $2.01(\mathrm{~s}, 3 \mathrm{H}), 2.97\left(\mathrm{dd}, 1 \mathrm{H}, J=12.0\right.$ and $\left.2.1 \mathrm{~Hz}, \mathrm{H}_{4^{\prime} \mathrm{a}}\right)$, $2.99\left(\mathrm{dd}, 1 \mathrm{H}, J=11.5\right.$ and $\left.20.4 \mathrm{~Hz}, \mathrm{H}_{3^{\prime \prime} \mathrm{a}}\right), 2.99$ (dd, $1 \mathrm{H}, J=14.8$ and $\left.21.47 \mathrm{~Hz}, \mathrm{H}_{3^{\prime \prime} \mathrm{a}}\right), 3.13(\mathrm{dd}, 1 \mathrm{H}$, $J=11.5$ and $\left.20.4 \mathrm{~Hz}, \mathrm{H}_{3^{\prime \prime} \mathrm{b}}\right), 3.70(\mathrm{dd}, 1 \mathrm{H}, J=8.8$ and $\left.12.0 \mathrm{~Hz}, \mathrm{H}_{4^{\prime} \mathrm{b}}\right), 4.10(\mathrm{q}, 4 \mathrm{H}, J=6.5 \mathrm{~Hz}), 6.61(\mathrm{dd}, 1 \mathrm{H}$, $J=2.1$ and $8.8 \mathrm{~Hz}), 7.45(\mathrm{~d}, 1 \mathrm{H}, J=7.7 \mathrm{~Hz}), 7.70(\mathrm{~d}$, $1 \mathrm{H}, J=7.7), 10.1$ (br s, NH). ${ }^{13} \mathrm{C} \mathrm{NMR}\left(\mathrm{CDCl}_{3}\right): \delta$ $16.60,17.50,25.10,29.95,46.12,63.10,63.18,87.14$, 129.05, 143.72, 154.16, 155.07, 163.42. 171.23. HRMS (FAB) calcd for $\left[\mathrm{M}^{+}\right] \mathrm{C}_{14} \mathrm{H}_{21} \mathrm{~N}_{4} \mathrm{O}_{6} \mathrm{P}: 372.3204$. Found: 372.3212. Anal. Calcd for $\mathrm{C}_{14} \mathrm{H}_{21} \mathrm{~N}_{4} \mathrm{O}_{6} \mathrm{P}: \mathrm{C}, 45.16 ; \mathrm{H}$, 5.68; N, 15.05. Found: C, 45.08; H, 5.73; N, 15.10.

5.6. diethyl[(5RS)-4,5-Dihydro-5-(3,4-dihydro-5-methyl2,4-dioxopyrimidin-1(2H)-yl)methylisoxazol-3-yl] methyl phosphonate $7 \mathrm{a}$

Starting from diethyl 2-(hydroxymino)ethyl phosphonate, compound $7 \mathbf{a}$ was obtained as a yellow oil $(65 \%$ yield). ${ }^{1} \mathrm{H}$ NMR $\left(\mathrm{CDCl}_{3}\right): \delta 1.31(\mathrm{t}, 6 \mathrm{H}, J=6.5 \mathrm{~Hz})$, $1.84(\mathrm{~d}, 3 \mathrm{H}, J=0.87 \mathrm{~Hz}), 2.95-2.99\left(\mathrm{~m}, 3 \mathrm{H}, \mathrm{H}_{4^{\prime} \mathrm{a}}\right.$ and $\left.\mathrm{H}_{3^{\prime \prime}}\right), 3.12\left(\mathrm{dd}, 1 \mathrm{H}, J=3.02\right.$ and $\left.13.5 \mathrm{~Hz}, \mathrm{H}_{4^{\prime} \mathrm{b}}\right), 3.57$ (dd, $1 \mathrm{H}, J=4.28$ and $14.28 \mathrm{~Hz}, \mathrm{H}_{5^{\prime \prime}}$ ), $3.95(\mathrm{dd}, 1 \mathrm{H}$, $J=3.02$ and $\left.14.28 \mathrm{~Hz}, \mathrm{H}_{5^{\prime \prime} \mathrm{b}}\right), 4.10(\mathrm{q}, 4 \mathrm{H}, J=6.5)$, $4.87\left(\mathrm{~m}, 1 \mathrm{H}, \mathrm{H}_{5^{\prime}}\right), 7.31(\mathrm{q}, 1 \mathrm{H}, J=0.87 \mathrm{~Hz}), 10.31(\mathrm{br}$ $\mathrm{s}, \mathrm{NH}) .{ }^{13} \mathrm{C}$ NMR $\left(\mathrm{CDCl}_{3}\right): \delta 12.37,16.49,16.57$, 
$27.17,40.35,50.67,62.88,63.00,78.65,110.66,141.71$, $151.79,152.56,164.88$. HRMS (FAB) calcd for $\left[\mathrm{M}^{+}\right]$ $\mathrm{C}_{14} \mathrm{H}_{22} \mathrm{~N}_{3} \mathrm{O}_{6} \mathrm{P}: 359.2890$. Found: 359.2896. Anal. Calcd for C, 46.80; H, 6.17; N, 11.70. Found: C, 46.76; H, 6.07; $\mathrm{N}, 11.78$.

\subsection{Diethyl[(5RS)-5-(5-fluoro-3,4-dihydro-2,4-dioxopyr- imidin-1(2H)-ylmethyl)-4,5-dihydroisoxazol-3-yl] methyl phosphonate $7 \mathrm{~b}$}

Starting from diethyl 2-(hydroxymino)ethyl phosphonate, compound $\mathbf{7 b}$ was obtained as a yellow oil $(70 \%$ yield). ${ }^{1} \mathrm{H}$ NMR $\left(\mathrm{CDCl}_{3}\right): \delta 1.34(\mathrm{t}, 6 \mathrm{H}, J=6.7 \mathrm{~Hz})$, $2.98\left(\mathrm{~m}, 3 \mathrm{H}, \mathrm{H}_{4^{\prime} \mathrm{a}}\right.$ and $\left.\mathrm{H}_{3^{\prime \prime}}\right), 3.12(\mathrm{dd}, 1 \mathrm{H}, J=14.8$ and $\left.22.0 \mathrm{~Hz}, \mathrm{H}_{3^{\prime \prime} \mathrm{a}}\right), 3.18(\mathrm{dd}, 1 \mathrm{H}, J=4.5$ and $13.3 \mathrm{~Hz}$, $\left.\mathrm{H}_{4^{\prime} \mathrm{b}}\right), 3.78\left(\mathrm{dd}, 1 \mathrm{H}, J=6.86\right.$ and $\left.14.55 \mathrm{~Hz}, \mathrm{H}_{5^{\prime} \mathrm{a}}\right), 3.97$ $(\mathrm{dd}, \quad 1 \mathrm{H}, J=3.02$ and $14.55 \mathrm{~Hz}), 4.10(\mathrm{q}, 4 \mathrm{H}$, $J=6.7 \mathrm{~Hz}), 4.93\left(\mathrm{~m}, 1 \mathrm{H}, \mathrm{H}_{5^{\prime}}\right), 7.5(\mathrm{~d}, 1 \mathrm{H}, J=5.8 \mathrm{~Hz})$, 10.00 (br s, NH). ${ }^{13} \mathrm{C}$ NMR $\left(\mathrm{CDCl}_{3}\right): \delta 16.26,16.34$, $26.50,40.00,50.57,62.73,62.92,78.22,129.55,139.50$, 149.98, 152.36, 156.41. HRMS (FAB) calcd for $\left[\mathrm{M}^{+}\right]$ $\mathrm{C}_{13} \mathrm{H}_{19} \mathrm{~N}_{3} \mathrm{O}_{6} \mathrm{FP}:$ 363.2864. Found: 363.2871. Anal. Calcd for $\mathrm{C}_{13} \mathrm{H}_{19} \mathrm{~N}_{3} \mathrm{O}_{6} \mathrm{FP}: \mathrm{C}, 42.98 ; \mathrm{H}, 5.27 ; \mathrm{N}, 11.56$. Found: C, 42.93; H, 5.32; N, 11.63.

\section{8. [(5RS)-5-(4-Acetylamino-2-oxo-2H-pyrimidin-1-y]- methyl)-4,5-dihydro-isoxazol-3-ylmethyl] phosphonic acid diethyl ester 7c}

Starting from diethyl 2-(hydroxymino)ethyl phosphonate, compound $7 \mathbf{c}$ was obtained as a yellow oil $(62 \%$ yield). ${ }^{1} \mathrm{H}$ NMR $\left(\mathrm{CDCl}_{3}\right): 1.33(\mathrm{t}, 6 \mathrm{H}, J=6.04 \mathrm{~Hz})$, $2.24(\mathrm{~s}, 3 \mathrm{H}), 2.90-3.04\left(\mathrm{~m}, 3 \mathrm{H}, \mathrm{H}_{4^{\prime} \mathrm{a}}\right.$ and $\left.\mathrm{H}_{3^{\prime \prime}}\right), 3.21$ (dd, $1 \mathrm{H}, J=4.12$ and $\left.10.41 \mathrm{~Hz}, \mathrm{H}_{4^{\prime} \mathrm{b}}\right), 3.72(\mathrm{dd}, 1 \mathrm{H}$, $J=7.96$ and $\left.13.73 \mathrm{~Hz}, \mathrm{H}_{5^{\prime \prime} \mathrm{a}}\right), 4.08-4.20\left(\mathrm{~m}, 5 \mathrm{H}, \mathrm{H}_{5^{\prime \prime} \mathrm{b}}\right.$ and $\left.\mathrm{CH}_{2} \mathrm{O}\right), 4.97\left(\mathrm{~m}, 1 \mathrm{H}, \mathrm{H}_{5^{\prime} \mathrm{a}}\right), 7.42(\mathrm{~d}, 1 \mathrm{H}$, $J=7.41 \mathrm{~Hz}), 7.68(\mathrm{~d}, 1 \mathrm{H}, J=7.41 \mathrm{~Hz}), 10.23$ (bs, $\mathrm{NH}) .{ }^{13} \mathrm{C}$ NMR $\left(\mathrm{CDCl}_{3}\right): \delta 17.31,17.45,26.30,30.27$, $40.51, \quad 50.57,62.96,66.13,84.10,120.02,125.32$, 150.28, 156.48, 163.47, 171.29. HRMS (FAB) calcd for $\left[\mathrm{M}^{+}\right] \mathrm{C}_{15} \mathrm{H}_{23} \mathrm{~N}_{4} \mathrm{O}_{6} \mathrm{P}: 386.3474$. Found: 386.3469. Anal. Calcd for C, 46.63; H, 6.0; N, 14.50. Found: C, 46.58; $\mathrm{H}, 6.17 ; \mathrm{N}, 14.58$.

\section{Biological assays}

\subsection{Evaluation of toxicity}

Toxicity was evaluated by a commercial viability assay (CellTiter $96{ }^{\circledR} \mathrm{AQ}$ ueous One Solution Assay, Promega Co., Madison WI), according to manufacturer's instructions. This assay is based on the principle that cells, at death, rapidly lose the ability to reduce MTS tetrazolium. Briefly, Molt-3 and Vero cells were cultured in optimal culture conditions for $20 \mathrm{~h}$ in 96-well plates, in the absence of the compounds or in their presence, at concentrations ranging from 1 to $400 \mu \mathrm{M}$. At the end of the incubation time, the MTS-tetrazolium-based reagent was added to each well. After a further incubation of one hour at $37{ }^{\circ} \mathrm{C}$ in a humidified, $5 \% \mathrm{CO}_{2}$ atmosphere, the absorbance of the samples was recorded at $490 \mathrm{~nm}$ using a 96-well spectrophotometer. The assays were performed in triplicate. The cytotoxic concentrations $20\left(\mathrm{CC}_{20}\right)$ were calculated as the concentrations of the compounds required to cause $20 \%$ reduction of absorbance values.

\subsection{Anti-HSV assay}

The antiviral activity towards herpes simplex virus type 1 (HSV-1) and herpes simplex virus type 2 (HSV-2) was assayed by standard plaque reduction assays on Vero cells in six-well plates. The compounds were added to the wells to obtain final concentrations ranging from 1 to $400 \mu \mathrm{M}$. For compounds showing a $\mathrm{CC}_{20}$ lower than $400 \mu \mathrm{M}$, the maximal concentration tested for anti-HSV activity was that immediately higher than the calculated $\mathrm{CC}_{20}$. The effective concentrations $50\left(\mathrm{EC}_{50}\right)$ were calculated as the concentrations of the compounds required to cause $50 \%$ reduction of plaque formation.

\subsection{Reverse-transcriptase inhibition assay}

The capacity of the described compounds to inhibit avian myeloblastosis virus RT (Promega Co.) activity was investigated by evaluating their activity towards cDNA. Generation from an RNA template using a cell-free RT reaction assay, we have recently described. ${ }^{13}$ This assay is based on routinely adopted RT-PCR procedures. The reactions were performed in the presence or in the absence of the activated compounds, at the concentrations of $10 \mu \mathrm{M}, 1 \mu \mathrm{M}, 100 \mathrm{nM}, 10 \mathrm{nM}$ and $1 \mathrm{nM}$, for $1 \mathrm{~h}$ at $37^{\circ} \mathrm{C}$. The newly synthesized compounds and AZT (Sigma-Aldrich Co.) were activated in vitro through incubation with a crude extract from $1 \times 10^{6}$ PBMCs, that served as enzyme supplier for phosphorylation processes. The effective concentrations $100\left(\mathrm{EC}_{100}\right)$ were determined as the concentrations of the compounds required to cause complete $(100 \%)$ inhibition of RTPCR products.

\section{Acknowledgment}

This work was partially supported by M.I.U.R. (F.I.R.B. 2003).

\section{References and notes}

1. (a) De Clercq, E. J. Med. Chem. 2005, 48, 1-16; (b) Qiu, X. L.; Qing, F. L. Bioorg. Med. Chem. 2005, 13, 277-283; (c) Chen, X.; Zhou, W.; Schinazi, R. F.; Chu, C. K. J. Org. Chem. 2004, 69, 6034-6041; (d) Siddiqui, M. A.; Hughes, S. H.; Boyer, P. L.; Mitsuya, H.; Van, Q. N.; George, C.; Sarafinanos, S. G.; Marquez, V. E. A. J. Med. Chem. 2004, 47, 5041-5048;; (e) Ferrero, M.; Gotor, V. Chem. Rev. 2000, 100, 4319-4347; (f) Chu, C. K.; Baker, D. C. In Nucleosides and Nucleotides as Antitumor and Antiviral Agents; Plenum Press: New York, 1993.

2. Chong, Y.; Gumina, G.; Chu, C. K. Tetrahedron: Asymmetry 2000, 11, 4853-4875.

3. (a) Freeman, S.; Gardiner, J. M. Mol. Biotechnol. 1996, 5, 125-137; (b) Chen, J.; Sambaiah, T.; Illarionov, B.; Fischer, M.; Bacher, A.; Cushman, M. J. Org. Chem. 2004, 69, 6996-7003; (c) Hakimelahi, G. H. U.S. Patent 
Appl., 2004, CODEN: USXXCO US 2004002475 A1 20040101 CAN 140:59903; (d) Amblard, F.; Aucagne, V.; Guenot, P.; Schinazi, R. F.; Agrofoglio, L. A. Bioorg. Med. Chem. 2005, 13, 1239-1248.

4. (a) Rodriguez, J. B.; Comin, M. J. Mini-Rev. Med. Chem. 2003, 3, 95-114; (b) Ichikawa, E.; Kato, K. Curr. Med. Chem. 2001, 8, 385-423.

5. Merino, P. Curr. Med. Chem: Anti-infective Agents 2002, $1,389-411$.

6. Tronquet, J. M.; Zscly, M.; Cock, K.; De Villedam de Naide, F. Bioorg. Med. Chem. Lett. 1992, 2, 1723-1728.

7. (a) Chiacchio, U.; Corsaro, A.; Iannazzo, D.; Piperno, A.; Pistarà, V.; Rescifina, A.; Romeo, R.; Sindona, G.; Romeo, G. Tetrahedron: Asymmetry 2003, 14, 27172723; (b) Chiacchio, U.; Borrello, L.; Iannazzo, D.; Merino, P.; Piperno, A.; Rescifina, A.; Richichi, B.; Romeo, G. Tetrahedron: Asymmetry 2003, 14, 24192425; (c) Chiacchio, U.; Corsaro, A.; Rescifina, A.; Romeo, G.; Romeo, R. Tetrahedron: Asymmetry 2000, 11, 2045-2048.

8. Chiacchio, U.; Corsaro, A.; Iannazzo, D.; Piperno, A.; Pistarà, V.; Rescifina, A.; Romeo, R.; Valveri, V.; Mastino, A.; Romeo, G. J. Med. Chem. 2003, 46, 3696-3702.

9. (a) Gi, H. J.; Kiang, Y.; Schinazi, R. F.; Zhao, K. J. Org. Chem. 1997, 62, 88-92; (b) Xiang, Y.; Chen, J.; Schinazi, R. F.; Zhao, K. Bioorg. Med. Chem. Lett. 1996, 6, 1051-1054.

10. Johansson, N. G.; Eriksson, S. Acta Biochim. Pol. 1996, $43,143-160$.

11. (a) Wagner, C. R.; Iyer, V. V.; McIntee, E. J. Med. Res. Rev. 2000, 20, 417-451; (b) Shirokowa, E. A.; Jasko, M. V.; Khandazhinskaya, A. L.; Ivanov, A. V.; Yanvarev, D. V.; Skoblov, Y. S.; Mitkevitch, V. A.; Bocharov, E. V.; Pronyaeva, T. R.; Fedyuk, N. V.; Kukhanova, M. K.; Pokrovsky, A. G. J. Med. Chem. 2004, 47, 3606-3614.

12. Balzarini, J.; Holy, A.; Jindrich, J.; Naesens, L.; Snoeck, R.; Schols, D.; De Clercq, E. Antimicrob. Agents Chemother. 1993, 37, 332-338.

13. Chiacchio, U.; Balestrieri, E.; Macchi, B.; Iannazzo, D.; Piperno, A.; Rescifina, A.; Romeo, R.; Saglimbeni, M.; Sciortino, M. T.; Valveri, V.; Mastino, A.; Romeo, G. J. Med. Chem. 2005, 48, 1389-1394.
14. Guan, H. P.; Qiu, Y. L.; Ksebati, M. B.; Kern, E. R.; Zemlicka, J. Tetrahedron 2002, 58, 6047-6059.

15. (a) Holy, A.; De Clerq, E.; Votruba, I. In Nucleotide Analogues as Antiviral Agents; Martin, J. C., Ed.; American Chemical Society: Washington, DC, 1989; pp 55-71; (b) Harnden, M. R.; Parkin, A.; Parrot, M. J.; Perkins, R. M. J. Med. Chem. 1993, 36, 1343-1355; (c) Nguyen-Ba, P.; Turcotte, N.; Yuen, L.; Berdart, J.; Quimpere, M.; Chan, L. Bioorg. Chem. Med. Lett. 1998, $8,3561-3566$.

16. (a) Serafinowska, H. T.; Ashton, R. J.; Bailey, S.; Harnden, M. R.; Jackson, S. M.; Sutton, D. J. J. Med. Chem. 1995, 38, 1372-1379; (b) Kim, C. U.; Luh, B. Y.; Martin, J. C. J. Org. Chem. 1991, 56, 2642-2647.

17. Tsuge, O.; Kanemasa, S.; Suca, H.; Nakacawa, N. Bull. Chem. Soc. Jpn. 1987, 60, 2463-2473.

18. Dalpozzo, R.; De Nino, A.; Maiuolo, L.; Procopio, A.; Romeo, R.; Sindona, G. Synthesis 2002, 2, 172-174.

19. Adams, D. R.; Boyd, A. S. F.; Ferguson, R. Nucleosides Nucleotides 1998, 17, 1053-1074.

20. Chiacchio, U.; Corsaro, A.; Iannazzo, D.; Piperno, A.; Ristarà, V.; Procopio, A.; Rescifina, A.; Romeo, G.; Romeo, R.; Siciliano, M. C. R.; Valveri, E. Arkivoc 2002, 159-167.

21. (a) De Amici, M.; De Micheli, C.; Misani, V. Tetrahedron 1990, 46, 1975-1986; (b) De Amici, M.; Magri, P.; De Micheli, C.; Cateni, F.; Bovara, R.; Carrea, G.; Riva, S.; Canalone, G. J. Org. Chem. 1992, 57, 2825-2829; (c) Bacher, E.; Demnitz, F. W. J.; Hurni, T. Tetrahedron 1997, 53, 14317-14326.

22. Marquez, V. E.; Ezzitouni, A.; Russ, P.; Siddiqui, M. A.; Ford, H.; Feldman, R.; Mitsuya, H.; George, C.; Barchi J. Am. Chem. Soc. 1998, 120, 2780-2789.

23. (a) Lamberth, C. Org. Prep. Proc. Int. 2002, 34, 149-167; (b) Chiacchio, U.; Genovese, F.; Iannazzo, D.; Librando, V.; Merino, P.; Rescifina, A.; Romeo, R.; Procopio, A.; Romeo, G. Tetrahedron 2004, 60, 441-448.

24. Nkusi, G.; Neidlein, R. Journal fuer praktische Chemiel Chemiker-Zeitung 1992, 334, 278-280.

25. Coutouli-Argyropoulou, E.; Pilanidou, P. Tetrahedron Lett. 2003, 44, 3755-3758.

26. Sigel, H. Chem. Soc. Rev. 2004, 33, 191-200. 